\title{
Syntheses of protoporphyrin-IX derivatives bearing extended propionate side-chains
}

\author{
Robert T. Holmes, Jianming Lu, Celinah Mwakwari, and Kevin M. Smith* \\ Department of Chemistry, Louisiana State University, Baton Rouge, LA 70803, USA \\ E-mail: kmsmith@lsu.edu
}

Dedicated to Professor António M. d’A. Rocha Gonçalves

\begin{abstract}
In order to investigate the relationship between depth within membranes of singlet oxygen generation and effectiveness of photodynamic therapy of tumors, analogs of protoporphyrin-IX $\mathbf{1}$ bearing five $\mathbf{4}$ and seven $\mathbf{5}$ carbon atoms (in place of the 3-carbon atom chain in 1) were synthesized from monopyrrole precursors.
\end{abstract}

Keywords: Lipid bilayer, photodynamic therapy, protoporphyrin analogs, singlet oxygen

\section{Introduction}

Protoporphyrin-IX (PP-IX, 1) is justifiably known as the 'first' porphyrin. ${ }^{1}$ As its iron(II) complex, heme, it is the prosthetic group for a number of critically important heme proteins such as hemoglobins, myoglobins, cytochromes, catalases and peroxidases. In addition, PP-IX is also a biosynthetic precursor of chlorophylls and bacteriochlorophylls. ${ }^{2}$ X-Ray studies have shown that the vinyl-bearing rings of PP-IX are the most deeply embedded in the protein pockets of heme proteins and that the acid groups are consequently pointing to the polar outside of the protein cleft. ${ }^{3}$ With the notion that varying the length of the propionate side-chains in $\mathbf{1}$ might affect physiological activity of a heme protein by altering the position of the heme iron atom within the protein cleft, we had earlier synthesized the bis-acetic 2 and bis-butyric porphyrin $3 ;^{4}$ the bis-butyric porphyrin $\mathbf{3}$ was obtained by transformation of PP-IX. These porphyrins were also used in a study of the specificity of hemin oxidation by microsomal heme oxygenase. ${ }^{5}$

We were prompted to expand our syntheses to include other chain-lengthened derivatives of PP-IX [e.g. the bis-pentanoate 4 and bis-heptanoate 5 porphyrins] by the needs of ongoing collaborative studies with Dr. Benjamin Ehrenberg. These studies aimed to investigate the relationship between effectiveness of photodynamic therapy (PDT) and the distance within a 
membrane that singlet oxygen can be efficiently generated and used without diffusion out of the membrane.

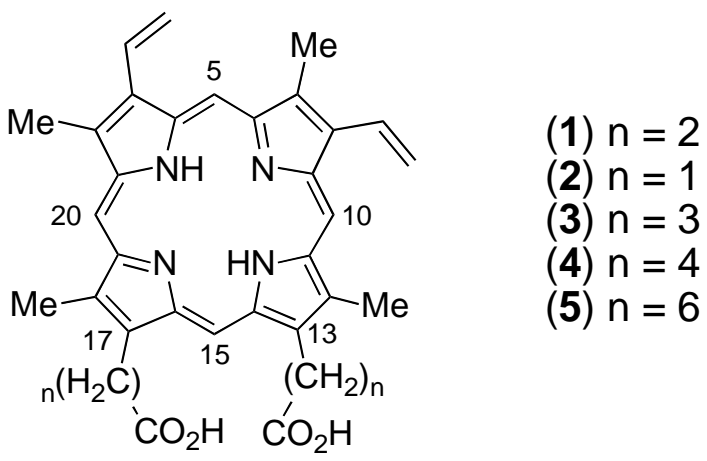

Singlet oxygen is the toxic species most often generated during the PDT process. ${ }^{6}$ It is a powerful oxidant and initiates critical damage to the tissues via apoptosis or necrosis of cancer cells when localized there. Evidence suggests ${ }^{7,8}$ that lipophilic sensitizers act, at least partially, in the bilayer membrane, increasing cell permeability, membrane rupture, and cell lysis in the plasma and organelle membranes. ${ }^{9}$ A disadvantage of PDT is that singlet oxygen can rapidly diffuse out of membranes because of its relatively long intrinsic lifetime (13-35 ms). ${ }^{10}$ Thus, an additional new criterion has been proposed by Ehrenberg for the design and choice of new PDT sensitizers; along with long-wavelength absorption (the obvious and most-often quoted advantage), vertical depth of penetration into cell membranes (see ' $X$ ' in Figure 1) should also be a criterion.

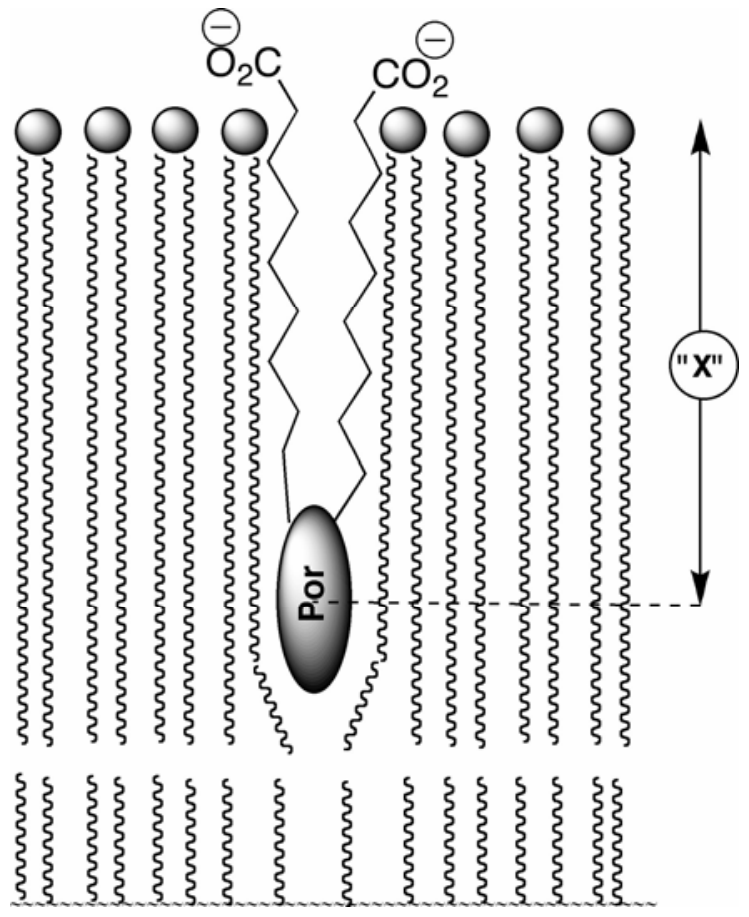

Figure 1. Cartoon showing vertical depth (' $X$ ') of a porphyrin (Por) in a lipid bilayer. 
To date five articles ${ }^{11-15}$ have reported our photochemical, photophysical and photobiological preliminary studies using the PP-IX analogs that we report herein, along with compounds $\mathbf{2}$ and $\mathbf{3}$ that were re-synthesized according to our literature procedures. ${ }^{4}$ In the first paper $^{11}$ we definitively showed that the photosensitization process is enhanced when the sensitizing chromophore is deeper into the lipid bilayer of liposomes. We next showed ${ }^{12}$ that lengthening of the 13- and 17-side-chains caused an increase in the lipophilicity and the liposome-binding constant. In another study ${ }^{13}$ it was shown, using two fluorescence quenching techniques (namely iodide ions from the aqueous phase and using spin-probe-labeled phospholipids), that vertical location of the photosensitizer chromophore in a membrane has an effect on its activity; the extent of membrane damage can be modulated by adjustment of the depth in the membrane, this being accomplished by synthetic variability of the 13- and 17-side-chain length. In the fourth paper $^{14}$ we showed that increased chain length in the corresponding hematoporphyrin-IX analogs of the synthetic PP-IX compounds imparts increased hydrophobicity, and that there is a strong $\mathrm{pH}$ dependence on the efficiency of fluorescence quenching by iodide; porphyrins in the neutral form penetrate deeper into the lipid bilayer and are less exposed to external quenching than when negatively charged at the carboxylic groups. Increasing the $\mathrm{pH}$ causes a significant decrease in the photosensitization efficiency in liposomes because protonation of the carboxylate groups allows the chromophore to sink deeper into the membrane, thus increasing the 'dwell-time' and effectiveness of the singlet oxygen produced upon irradiation. The fifth paper ${ }^{15}$ described an in vitro and in vivo comparison between PP-IX 1 and the synthetic PP analog 5 bearing a sevenmembered carboxylate chain at positions 13 and 17. The inactivation (by singlet oxygen) of WiDr and CT26 cells increased linearly with length of the 13- and 17-alkylcarboxylic chains, and in mice, tumors treated with $\mathbf{5}$ and light showed significant delay in their growth (compared with PP-IX, 1). ${ }^{15}$

\section{Results and Discussion}

Our synthetic targets were the bis-pentanoic 4 and bis-heptanoic 5 analogs of PP-IX (1). Using IUPAC nomenclature, the side-chain modifications were designed at the 13- and 17-positions. For economy in synthesis, the approach was designed such that a common dipyrromethane 6 was prepared. The lower halves of the derivatives, however, were more challenging and required the synthesis of novel pyrroles 7a,b. 
<smiles>Cc1c(Cc2[nH]c(C(=O)OCc3ccccc3)c(C)c2CCCl)[nH]c(CCCl)c1CCC(C)(C)C</smiles>

(6)<smiles>[R]c1c(C)[nH]c(C=O)c1C</smiles>

(7)

a $\mathrm{R}=\left(\mathrm{CH}_{2}\right)_{4} \mathrm{CO}_{2} \mathrm{Me}$

b $\mathrm{R}=\left(\mathrm{CH}_{2}\right)_{6} \mathrm{CO}_{2} \mathrm{Et}$

Beginning with the top half of the molecule, known dipyrromethane 6 was prepared as outlined in Scheme $1 .^{16}$ The desired unsymmetrical starting material was prepared from just one pyrrole 8, which was in turn prepared via a standard Knorr-type synthesis. Thallium(III) nitrate rearrangement of $\mathbf{8}$ in methanol gave the (methoxycarbonylmethyl)pyrrole (9), ${ }^{17,18}$ which was reduced with borane-THF to give the (2-hydroxyethyl)pyrrole 10. $\mathrm{S}_{\mathrm{N}} 2$ displacement with a chloride ion led to the key chloroethylpyrrole 11. ${ }^{17}$ This pyrrole was then either subjected to $\mathrm{Pb}(\mathrm{OAc})_{4}$ oxidation in acetic acid to yield the acetoxymethylpyrrole $\mathbf{1 2}$ or further manipulated to form a $t$-butyl pyrrole-carboxylate $\mathbf{1 3}$ by sulfuryl chloride oxidation followed by $t$-butanolysis, (Scheme 1$) ;{ }^{19}$ hydrogenation, iodination, and a second hydrogenation using Adams' catalyst then afforded the desired $\alpha$-free pyrrole 14. Coupling of these two pyrroles with K10 clay as catalyst in $\mathrm{CH}_{2} \mathrm{Cl}_{2}$ completed the synthesis of $\mathbf{6}$.

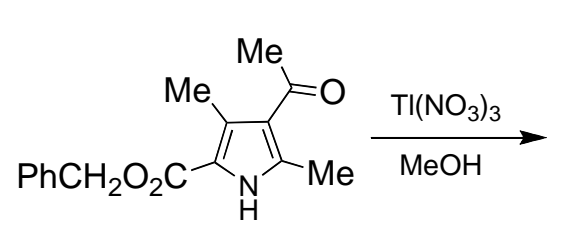

(8)

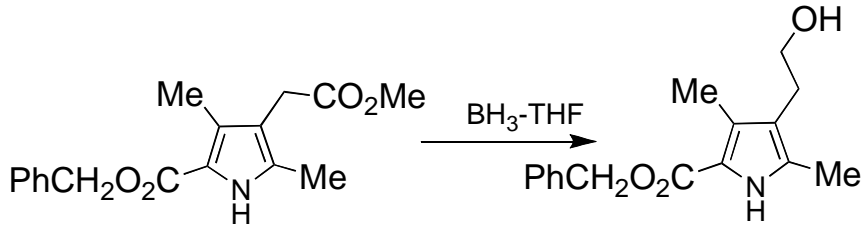

(9)
(10)

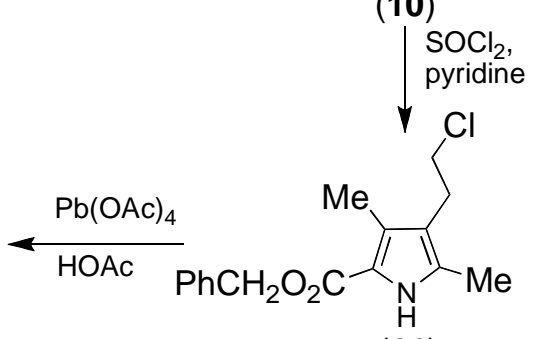

(11)
(6)

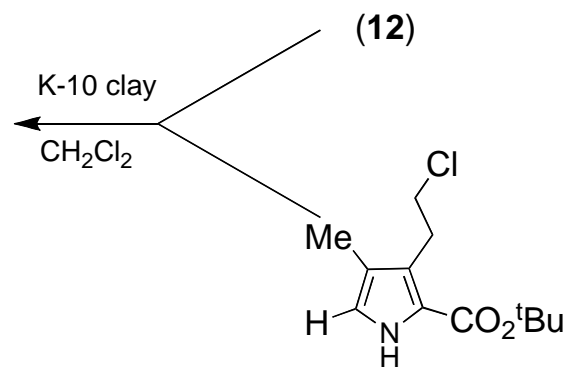

(14)

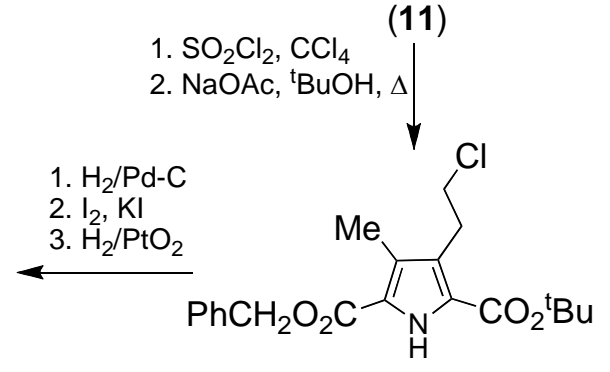

(13)

Scheme 1. Synthesis of the common dipyrromethane 6 . 
<smiles>CC(=O)CCc1c(C)[nH]c(C([O+])[O-])c1C</smiles>

(15)<smiles>[R]OC([R])([2H])O</smiles>

(17)

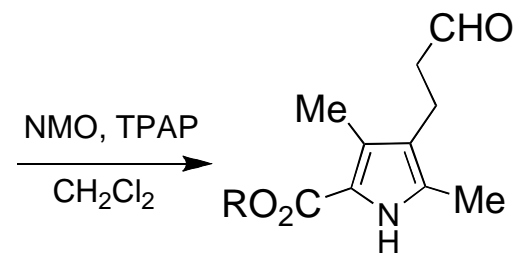

(16)

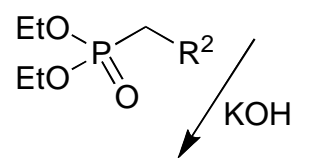<smiles>[R]CCCCc1c(C)[nH]c(C=O)c1C</smiles>

(7)

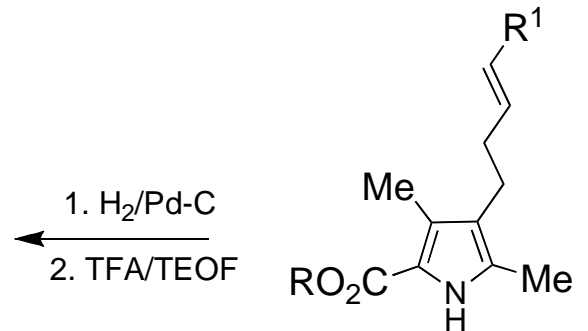

(18)

$$
\begin{aligned}
& \text { a } \mathrm{R}^{1}=\mathrm{CO}_{2} \mathrm{Me} \\
& \text { a } \mathrm{R}^{1}=\mathrm{CO}_{2} \mathrm{Me} \\
& \text { b } \mathrm{R}^{1}=\mathrm{CH}_{2} \mathrm{CH}_{2} \mathrm{CO}_{2} \mathrm{Me} \\
& \text { b } \mathrm{R}^{1}=\mathrm{CH}=\mathrm{CH}-\mathrm{CO}_{2} \mathrm{Et} \\
& \mathrm{R}=\mathrm{PhCH}_{2} \text { or }{ }^{\mathrm{t}} \mathrm{Bu} \\
& \mathrm{R}^{2}=\mathrm{CO}_{2} \mathrm{Me} \text { or } \mathrm{CH}=\mathrm{CHCO}_{2} \mathrm{Et}
\end{aligned}
$$

Scheme 2. Syntheses of the formylpyrroles 7a,b.

Turning to the lower portion of the targeted derivatives, pyrrole $\mathbf{7 a}$ and $\mathbf{7 b}$ required starting from known pyrrole 15; ${ }^{20}$ pyrrole aldehyde 16 was prepared by reduction of 15 with $\mathrm{BH}_{3}-\mathrm{THF}_{\text {to }}$ give 17 which was then oxidized using NMO and $\mathrm{TPAP}^{21}$ to give 16. The chain was then lengthened using the appropriate Horner-Wittig-Emmons reagent and base to give high yields of both acrylate pyrroles 18a and 18b. Catalytic hydrogenation, followed by formylation using TFA/TEOF led to the desired 2-formylpyrrole starting materials $\mathbf{7 a}$ and $\mathbf{7 b}$ (Scheme 2). 
<smiles>Cc1c(C(=O)OCc2ccccc2)[nH]c(Cc2[nH]c(C(=O)OCC(C)(C)C)c(CCCl)c2C)c1CCCl</smiles>

(6)

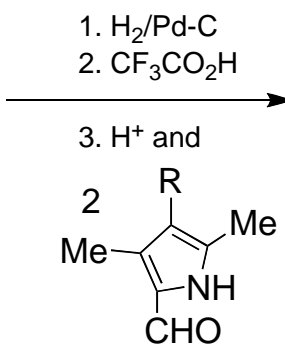

$(7 a, b)$

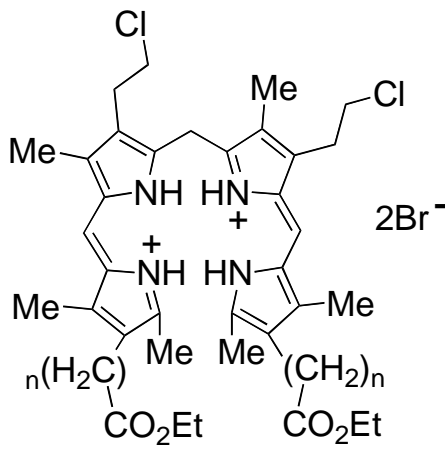

(19)

a $n=4$

b $n=6$

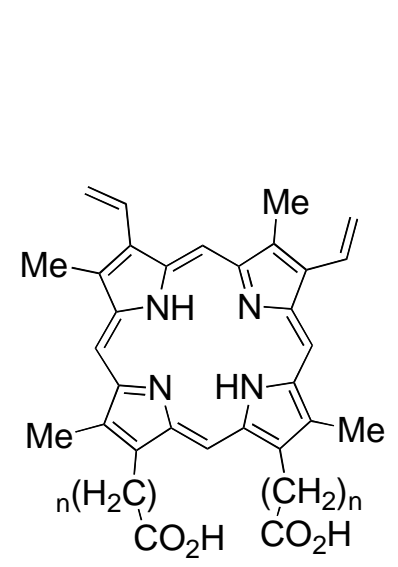

(4) $n=4$

(5) $n=6$

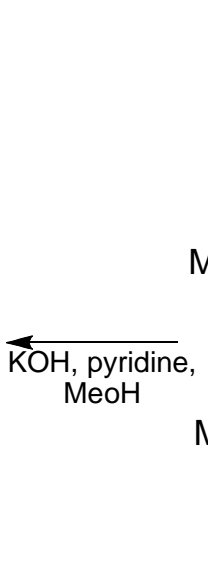

(21)

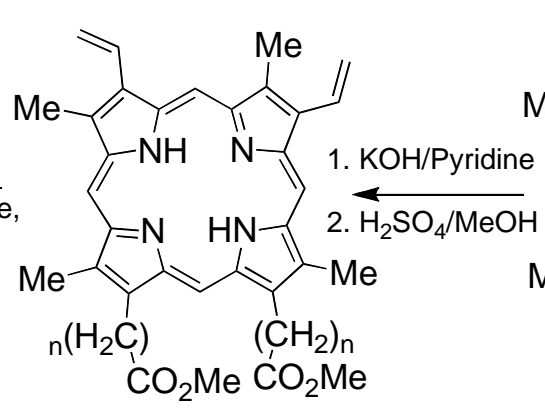

a $n=4$
$b n=6$
1. $\mathrm{Cu}(\mathrm{OAC})_{2}$, heat

2. $\mathrm{CF}_{3} \mathrm{CO}_{2} \mathrm{H} / \mathrm{H}_{2} \mathrm{SO}_{4}$
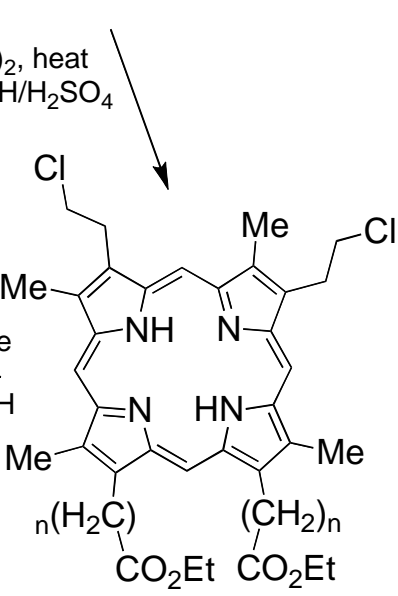

(20) $\begin{aligned} & \text { a } n=4 \\ & \text { b } n=6\end{aligned}$

Scheme 3. Syntheses of porphyrins (4), and (5) via a,c-biladiene salts (19).

Removal of both ester protecting groups followed by condensation with the appropriate monoformyl pyrrole led to the corresponding a,c-biladienes 19a,b. These were difficult to crystallize and to purify, so were used directly in a copper-induced cyclization reaction ${ }^{22}$ to yield the porphyrins 20a,b in yields ranging from 30 to $42 \%$ (Scheme 3). Dehydrohalogenation of the porphyrins 20a,b in the presence of base led to the required dimethyl esters of the divinyl products 21a,b. During this step, partial hydrolysis of the esters was detected by TLC, so reesterification (using $5 \% \mathrm{H}_{2} \mathrm{SO}_{4}$ in $\mathrm{MeOH}$ ) was carried out, and the products 21a,b were purified using silica gel column chromatography. Once isolated, the esters were carefully hydrolyzed at room temperature in the presence of pyridine, $\mathrm{KOH}$, and $\mathrm{MeOH}$ to yield the desired PP-IX analogs 4 and 5. 


\section{Experimental Section}

General Procedures. Melting points were measured on a Thomas/Bristoline microscopic hot stage apparatus and were uncorrected. Silica gel 60 (70-230 mesh, Merck) was used for column chromatography. ${ }^{1} \mathrm{H}-\mathrm{NMR}$ spectra were obtained in $\mathrm{CDCl}_{3}$ at $300 \mathrm{MHz}$ using a General Electric QE300 spectrometer; chemical shifts are expressed in ppm relative to chloroform (7.26 ppm). Elemental analyses were performed at the Midwest Microlab. Inc., Indianapolis, Indiana, USA. Electronic absorption spectra were measured in dichloromethane solution using a HewlettPackard 8450A spectrophotometer. Mass spectra were obtained at the Mass Spectrometry Facility, University of California, San Francisco, California, USA and the Mass Spectrometry Facility in the Department of Chemistry, Louisiana State University.

Benzyl 4-(3-hydroxypropyl)-3,5-dimethylpyrrole-2-carboxylate, (17, $\mathbf{R}=\mathbf{P h C H}_{2}$ ). Pyrrole $15^{22}$ (10.00 g, $0.0317 \mathrm{~mol}$ ) was placed in a $1000 \mathrm{~mL}$ round-bottomed flask and dissolved in THF $(300 \mathrm{~mL})$. An addition funnel, affixed with a nitrogen inlet was attached and $\mathrm{BH}_{3}$-THF (1M, 70 $\mathrm{mL}$ ) was dripped in slowly while the solution was stirred over ice. Once the addition was complete the reaction was allowed to continue at room temperature overnight. $\mathrm{MeOH}$ was slowly added to quench the reaction and the solution was evaporated to dryness and re-suspended in $\mathrm{CH}_{2} \mathrm{Cl}_{2}$ before being passed through a pad of silica gel. The resulting crude material was dissolved in a minimum amount of $\mathrm{CH}_{2} \mathrm{Cl}_{2}$ and petroleum ether was added slowly to give the title compound 17, $\mathrm{R}=\mathrm{PhCH}_{2}$ as an oil (7.2 g, 80\% yield). ${ }^{1} \mathrm{H}-\mathrm{NMR}$ : $\left(\mathrm{CDCl}_{3}\right) \delta 8.48$ (bs, $1 \mathrm{H}, \mathrm{N}-$ H), 7.36 (m, 5H, Ar-H), 5.28 (s, 2H, Ar- $\mathrm{CH}_{2}-$ ), 3.64 (t, 2H, HO-CH $\mathbf{C H}_{2}-\mathrm{CH}_{2}-\mathrm{CH}_{2}$ ), 2.46 (t, 2H, $\mathrm{HO}-\mathrm{CH}_{2}-\mathrm{CH}_{2}-\mathrm{CH}_{2}-$ ), 2.29 (s, 3H, $-\mathrm{CH}_{3}$ ), 2.20 (s, 3H, -CH $\mathrm{CH}_{3}, 1.72$ (m, 2H, HO-CH $2_{2}-\mathrm{CH}_{2}-\mathrm{CH}_{2}-$ ). HRMS: $\mathrm{C}_{17} \mathrm{H}_{21} \mathrm{NO}_{3}$ requires $\mathrm{m} / \mathrm{z}$ 287.15213. Found 287.1521.

tert-Butyl 4-(3-hydroxypropyl)-3,5-dimethylpyrrole-2-carboxylate $\left(17, \mathbf{R}={ }^{\mathbf{t}} \mathbf{B u}\right)$. Using the same procedure as reported above, the title pyrrole ( $2.5 \mathrm{~g}, 91 \%$ yield) was obtained as an oil. ${ }^{1} \mathrm{H}-$ NMR: $\left(\mathrm{CDCl}_{3}\right) \delta 8.45$ (bs, 1H, N-H), 3.64 (bt, 2H, HO-CH${ }_{2}-\mathrm{CH}_{2}-\mathrm{CH}_{2}-$ ), 2.46 (t, 2H, HO-CH $2^{-}$ $\mathrm{CH}_{2}-\mathrm{CH}_{2}$ ), 2.25 (s, 3H, $-\mathrm{CH}_{3}$ ), 2.21 (s, 3H, $-\mathrm{CH}_{3}$ ), $\delta 1.70$ (m, 2H, HO-CH${ }_{2}-\mathrm{CH}_{2}-\mathrm{CH}_{2}-$ ), 1.56 (s, 9H, -C(CH$\left.)_{3}\right)$. HRMS: $\mathrm{C}_{14} \mathrm{H}_{23} \mathrm{NO}_{3}$ requires $\mathrm{m} / \mathrm{z}$ 252.16778. Found 253.1672.

Benzyl 4-(2-formylethyl)-3,5-dimethylpyrrole-2-carboxylate, (16, $\mathbf{R}=\mathbf{P h C H}$ ). To a $500 \mathrm{~mL}$ round-bottomed flask was added 3-hydroxyethylpyrrole 16, $\mathrm{R}=\mathrm{PhCH}_{2}$ (5 g, $0.0174 \mathrm{~mol}$ ), distilled $\mathrm{CH}_{2} \mathrm{Cl}_{2}$ (200 mL), and molecular drying sieves. N-Methylmorpholine-N-oxide (NMO, $2.1 \mathrm{~g}, 0.0174 \mathrm{~mol}$ ) was then added followed by the addition of tetrapropylammonium perruthenate (TPAP, $0.5 \mathrm{~g}$ ). The mixture was stirred under a stream of nitrogen for $45 \mathrm{~min}$, after which time the solution was partitioned between $\mathrm{H}_{2} \mathrm{O}$ and $\mathrm{CH}_{2} \mathrm{Cl}_{2}$. The organic layer was evaporated and eluted through a silica gel column prepared in $1 \% \mathrm{MeOH} / \mathrm{CH}_{2} \mathrm{Cl}_{2}$. A clear colorless compound was collected which was crystallized from a minimum of $\mathrm{CH}_{2} \mathrm{Cl}_{2}$ and petroleum ether. The white solid obtained proved to be the title compound $16, \mathrm{R}=\mathrm{PhCH}_{2}$, (3.1 g, 63\% yield), mp 80-82 ${ }^{\circ} \mathrm{C} .{ }^{1} \mathrm{H}-\mathrm{NMR}:\left(\mathrm{CDCl}_{3}\right) \delta 9.78$ (s, $1 \mathrm{H},-\mathrm{CH}_{2}-\mathrm{CH}_{2}-\mathrm{CHO}$ ), 8.50 (bs, $1 \mathrm{H}$, N-H), 7.39 (m, 5H, Ar-H), 5.28 (s, 2H, Ar- $\mathrm{CH}_{2}-$ ), 2.70 (t, 2H, - $\mathrm{CH}_{2}-\mathrm{CH}_{2}-\mathrm{CHO}$ ), 2.57 (t, 2H, - 
$\mathrm{CH}_{2}-\mathrm{CH}_{2}-\mathrm{CHO}$ ), 2.28 (s, 3H, $-\mathrm{CH}_{3}$ ), 2.21 (s, 3H, $-\mathrm{CH}_{3}$ ). HRMS: $\mathrm{C}_{17} \mathrm{H}_{19} \mathrm{NO}_{3}$ requires $\mathrm{m} / \mathrm{z}$ 251.15213. Found 251.1525.

tert-Butyl 4-(2-formylethyl)-3,5-dimethylpyrrole-2-carboxylate, (16, $\left.\mathbf{R}={ }^{\mathbf{t}} \mathbf{B u}\right)$. Using the same procedure as reported above, the title pyrrole was obtained (3.8 g, 75\% yield), mp 105-107 ${ }^{\circ} \mathrm{C} .{ }^{1} \mathrm{H}-\mathrm{NMR}:\left(\mathrm{CDCl}_{3}\right) \delta 9.78$ (s, $\left.1 \mathrm{H},-\mathrm{CH}_{2}-\mathrm{CH}_{2}-\mathrm{CHO}\right), 8.42$ (bs, $\left.1 \mathrm{H}, \mathrm{N}-\mathrm{H}\right), 2.69$ (t, 2H, $-\mathrm{CH}_{2}-$ $\mathrm{CH}_{2}-\mathrm{CHO}$ ), 2.57 (tr, 2H, - $\mathrm{CH}_{2}-\mathrm{CH}_{2}-\mathrm{CHO}$ ), 2.24 (s, 3H, - $\mathrm{CH}_{3}$ ), 2.20 (s, 3H, -CH $\mathrm{CH}_{3}, 1.55$ (s, 9H, $\left.\mathrm{C}\left(\mathrm{CH}_{3}\right)_{3}\right)$. HRMS: $\mathrm{C}_{14} \mathrm{H}_{21} \mathrm{NO}_{3}$ requires $\mathrm{m} / \mathrm{z}$ 251.15213. Found 251.1525.

Benzyl 4-(4-methoxycarbonyl-3-butenyl)-3,5-dimethylpyrrole-2-carboxylate

(18a). (Formylethyl)pyrrole 16, $\mathrm{R}=\mathrm{PhCH}_{2}(3.1 \mathrm{~g}, 0.0109 \mathrm{~mol})$ was placed in a $250 \mathrm{~mL}$ roundbottomed flask. THF (150 mL), KOH (800 mg), and methyl diethylphosphonoacetate (3.4g, $0.0163 \mathrm{~mol}$ ) were then added. The reaction was allowed to stir under nitrogen for $3 \mathrm{~h}$ after which time it was extracted $3 \mathrm{x}$ with $\mathrm{CH}_{2} \mathrm{Cl}_{2}$ and $\mathrm{H}_{2} \mathrm{O}$. The organic layers were combined, washed with brine and dried over $\mathrm{Na}_{2} \mathrm{SO}_{4}$. Upon evaporation, the crude oil was eluted through a silica gel column previously prepared in $1 \% \mathrm{MeOH} / \mathrm{CH}_{2} \mathrm{Cl}_{2}$. The title compound as a clear oil (3.7 $\mathrm{g}$, $100 \%$ yield, was obtained which slowly crystallized, mp $75-76{ }^{\circ} \mathrm{C} .{ }^{1} \mathrm{H}-\mathrm{NMR}$ : $\left(\mathrm{CDCl}_{3}\right) \delta 8.50$ (bs, $1 \mathrm{H}, \mathrm{N}-\mathbf{H}$ ), 7.43 (m, 5H, Ar-H), 6.96 (d of t, $1 \mathrm{H},-\mathrm{CH}_{2}-\mathrm{CH}_{2}-\mathrm{CH}=\mathrm{CH}-\mathrm{CO}_{2} \mathrm{CH}_{3}$ ), 5.81 (d, 1H, $\mathrm{CH}_{2}-\mathrm{CH}_{2}-\mathrm{CH}=\mathrm{CH}-\mathrm{CO}_{2} \mathrm{CH}_{3}$ ), 5.28 (s, $2 \mathrm{H}, \mathrm{Ar}-\mathrm{CH}_{2}-$ ), 3.72 (s, 3H, $-\mathrm{CH}_{2}-\mathrm{CH}_{2}-\mathrm{CH}=\mathrm{CH}-\mathrm{CO}_{2} \mathrm{CH}_{3}$ ), 2.51 (t, 2H, $\left.-\mathrm{CH}_{2}-\mathrm{CH}_{2}-\mathrm{CH}=\mathrm{CH}-\mathrm{CO}_{2} \mathrm{CH}_{3}\right), 2.28$ (m, 2H, $-\mathrm{CH}_{2}-\mathrm{CH}_{2}-\mathrm{CH}=\mathrm{CH}-\mathrm{CO}_{2} \mathrm{CH}_{3}$ ), 2.27 (s, $3 \mathrm{H},-\mathrm{CH}_{3}$ ), 2.17 (s, 3H, $-\mathrm{CH}_{3}$ ). HRMS: $\mathrm{C}_{20} \mathrm{H}_{23} \mathrm{NO}_{4}$ requires $\mathrm{m} / \mathrm{z}$ 341.16270. Found 341.1624.

tert-Butyl 4-(6-ethoxycarbonyl-3,5-hexadienyl)-3,5-dimethylpyrrole-2-carboxylate (18b). (Formylethyl)pyrrole 16, $\mathrm{R}={ }^{\mathrm{t}} \mathrm{Bu}(5.0 \mathrm{~g}, 0.019 \mathrm{~mol})$ was placed in a $250 \mathrm{~mL}$ round-bottomed flask. THF (150 mL), KOH (800 mg), and triethyl 4-phosphonocrotonate (7.5g, $0.03 \mathrm{~mol}$ ) were then added. The reaction mixture was allowed to stir under nitrogen for $3 \mathrm{~h}$ after which time it was extracted $3 x$ with $\mathrm{CH}_{2} \mathrm{Cl}_{2}$ and $\mathrm{H}_{2} \mathrm{O}$. The organic layers were combined, washed with brine and dried over $\mathrm{Na}_{2} \mathrm{SO}_{4}$. After evaporation, the crude oil was eluted through a silica gel column previously prepared in $1 \% \mathrm{MeOH} / \mathrm{CH}_{2} \mathrm{Cl}_{2}$. A clear oil of the title compound (5.5 g, $80 \%$ yield) resulted which could not be crystallized or precipitated. ${ }^{1} \mathrm{H}-\mathrm{NMR}$ : $\left(\mathrm{CDCl}_{3}\right) \delta 8.96$ (bs, $\left.1 \mathrm{H}, \mathrm{N}-\mathrm{H}\right)$, $7.21\left(\mathrm{~m}, 1 \mathrm{H},-\mathrm{CH}_{2}-\mathrm{CH}_{2}-\mathrm{CH}=\mathrm{CH}-\mathrm{CH}=\mathrm{CH}-\mathrm{CO}_{2} \mathrm{CH}_{2} \mathrm{CH}_{3}\right), 6.14\left(\mathrm{~m}, 2 \mathrm{H},-\mathrm{CH}_{2}-\mathrm{CH}_{2}-\mathrm{CH}=\mathrm{CH}-\right.$ $\left.\mathrm{CH}=\mathrm{CH}-\mathrm{CO}_{2} \mathrm{CH}_{2} \mathrm{CH}_{3}\right), 5.78\left(\mathrm{~d}, 1 \mathrm{H},-\mathrm{CH}_{2}-\mathrm{CH}_{2}-\mathrm{CH}=\mathrm{CH}-\mathrm{CH}=\mathrm{CH}-\mathrm{CO}_{2} \mathrm{CH}_{2} \mathrm{CH}_{3}\right), 4.20$ (q, 2H, $\left.\mathrm{CO}_{2}-\mathrm{CH}_{2}-\mathrm{CH}_{3}\right), 2.50\left(\mathrm{t}, 2 \mathrm{H},-\mathrm{CH}_{2}-\mathrm{CH}_{2}-\mathrm{CH}=\mathrm{CH}-\mathrm{CH}=\mathrm{CH}-\mathrm{CO}_{2} \mathrm{CH}_{2} \mathrm{CH}_{3}\right), 2.28\left(\mathrm{~m}, 2 \mathrm{H},-\mathrm{CH}_{2}-\right.$ $\left.\mathrm{CH}_{2}-\mathrm{CH}=\mathrm{CH}-\mathrm{CH}=\mathrm{CH}-\mathrm{CO}_{2} \mathrm{CH}_{2} \mathrm{CH}_{3}\right), 2.25$ (s, 3H, $\left.-\mathrm{CH}_{3}\right), 2.19$ (s, 3H, $\left.-\mathrm{CH}_{3}\right), 1.57$ (s, 9H, - $\left(\mathrm{CH}_{3}\right)$ 3), 1.30 (t, 3H, $-\mathrm{CO}_{2}-\mathrm{CH}_{2}-\mathrm{CH}_{3}$ ). HRMS: $\mathrm{C}_{20} \mathrm{H}_{29} \mathrm{NO}_{4}$ requires $\mathrm{m} / \mathrm{z}$ 347.20964. Found 347.2097. 2-Formyl-4-(4-methoxycarbonylbutyl)-3,5-dimethypyrrole (7a). Acrylate pyrrole 18a, $\mathrm{R}=$ $\mathrm{PhCH}_{2}$ (3.3 g, 9.67 $\times 10^{-3} \mathrm{~mol}$ ) was hydrogenated under $\mathrm{H}_{2}$ gas at room temperature and atmospheric pressure using $\mathrm{Pd} / \mathrm{C}(0.30 \mathrm{~g})$ as a catalyst and THF $(150 \mathrm{~mL})$ as solvent. Upon completion of reaction, the catalyst was filtered off and the solvent evaporated. This product was not isolated, but was instead directly subjected to treatment with TFA (50 mL) while stirring under nitrogen in an ice bath. After 15 min had passed, triethyl orthoformate (25 mL) was added and the reaction mixture was allowed to stir an additional $3 \mathrm{~h}$ as it reached room temperature. The solution was then partitioned between $\mathrm{CH}_{2} \mathrm{Cl}_{2}$ and water. The organic layer was neutralized 
with a saturated solution of $\mathrm{NaHCO}_{3}$. The resulting organic layer was dried over $\mathrm{Na}_{2} \mathrm{SO}_{4}$ and evaporated to give a dark solid. This solid was re-suspended in a minimum of $\mathrm{CH}_{2} \mathrm{Cl}_{2}$ and eluted through a silica gel column prepared in $\mathrm{CH}_{2} \mathrm{Cl}_{2}$. A clear oil which proved to be the title compound was collected (2.2 g, 96\%) and slowly crystallized (mp 70-72 $\left.{ }^{\circ} \mathrm{C}\right) .{ }^{1} \mathrm{H}-\mathrm{NMR}$ : $\left(\mathrm{CDCl}_{3}\right)$ $\delta 9.45$ (s, 1H, -CHO), 9.20 (bs, $1 \mathrm{H},-\mathrm{NH}$ ), 3.66 (s, 3H, $-\mathrm{CO}_{2}-\mathrm{CH}_{3}$ ), 2.37 (m, 4H, - $\mathrm{CH}_{2}-\mathrm{CH}_{2}-\mathrm{CH}_{2-}$ $\left.\mathrm{CH}_{2}-\mathrm{CO}_{2} \mathrm{CH}_{3}\right), 2.16\left(\mathrm{~s}, 3 \mathrm{H},-\mathrm{CH}_{3}\right), 2.13\left(\mathrm{~s}, 3 \mathrm{H},-\mathrm{CH}_{3}\right), 1.62\left(\mathrm{~m}, 2 \mathrm{H},-\mathrm{CH}_{2}-\mathrm{CH}_{2}-\mathrm{CH}_{2}-\mathrm{CH}_{2}-\right.$ $\left.\mathrm{CO}_{2} \mathrm{CH}_{3}\right), 1.48\left(\mathrm{~m}, 2 \mathrm{H},-\mathrm{CH}_{2}-\mathrm{CH}_{2}-\mathrm{CH}_{2}-\mathrm{CH}_{2}-\mathrm{CO}_{2} \mathrm{CH}_{3}\right)$. HRMS: $\mathrm{C}_{13} \mathrm{H}_{19} \mathrm{NO}_{3}$ requires $\mathrm{m} / \mathrm{z}$ 237.13648. Found 237.1360.

2-Formyl-4-(6-ethoxycarbonylhexyl)-3,5-dimethypyrrole (7b). Using the same procedure as reported above, the title pyrrole was obtained (1.7 g, 38\% yield), mp 52-55 ${ }^{\circ} \mathrm{C}$. ${ }^{1} \mathrm{H}-\mathrm{NMR}$ : $\left(\mathrm{CDCl}_{3}\right) \delta 9.45$ (s, 1H, -CHO), 9.35 (bs, 1H, -NH), 4.13 (q, 2H, -CO-CH${ }_{2}-\mathrm{CH}_{3}$ ), 2.34 (m, 4H, $\mathrm{CH}_{2}-\mathrm{CH}_{2}-\mathrm{CH}_{2}-\mathrm{CH}_{2}-\mathrm{CH}_{2}-\mathrm{CH}_{2}-\mathrm{CO}_{2}-\mathrm{CH}_{2}-\mathrm{CH}_{3}$ ), 2.23 (s, 3H, - $\mathrm{CH}_{3}$ ), 2.19 (s, 3H, - $\mathrm{CH}_{3}$ ), 1.48-1.31 (m, 8H, $-\mathrm{CH}_{2}-\mathrm{CH}_{2}-\mathrm{CH}_{2}-\mathrm{CH}_{2}-\mathrm{CH}_{2}-\mathrm{CH}_{2}-\mathrm{CO}_{2}-\mathrm{CH}_{2}-\mathrm{CH}_{3}$ ), 1.24 (t, 3H, $-\mathrm{CO}_{2}-\mathrm{CH}_{2}-\mathrm{CH}_{3}$ ). HRMS: $\mathrm{C}_{15} \mathrm{H}_{23} \mathrm{NO}_{3}$ requires $\mathrm{m} / \mathrm{z}$ 279.18343. Found 279.1836 .

\section{2,4-Bis(2-chloroethyl)-6,7-bis(4-methoxycarbonylbutyl)-1,3,5,8-tetramethyl-porphyrin}

(20a). The dipyrromethane 6 (414 mg, 7.78x10 $\left.10^{-4} \mathrm{~mol}\right)$ in THF (25mL) containing 10\% Pd-C (40 $\mathrm{mg}$ ) was hydrogenated at atmospheric pressure and room temperature until uptake of hydrogen was complete. The solution was filtered through a bed of Celite and the solvent was evaporated to dryness to give a white solid. In a $100 \mathrm{~mL}$ round-bottomed flask over ice was placed the dipyrromethane carboxylic acid $\left(0.344 \mathrm{~g}, 7.78 \times 10^{-4} \mathrm{~mol}\right)$ and TFA $(25 \mathrm{~mL})$ was added; the mixture was stirred under nitrogen for $15 \mathrm{~min}$. Formylpyrrole 7a $\left(0.360 \mathrm{~g}, 1.52\right.$ x $\left.10^{-3} \mathrm{~mol}\right)$ dissolved in $15 \mathrm{~mL}$ of $\mathrm{MeOH}$ was then added directly. A color change from yellow to dark red was observed over time and the reaction was monitored using visible light. After $2 \mathrm{~h}, \mathrm{HBr}$ gas was bubbled into the solution and then ether $(50 \mathrm{~mL})$ was added to precipitate the a,c-biladiene salt 19a. This compound was collected and used directly in the next step. This crude a,cbiladiene dihydrobromide 19a was placed in a $100 \mathrm{~mL}$ round-bottomed flask and dissolved in $\mathrm{DMF}(40 \mathrm{~mL}) \cdot \mathrm{Cu}(\mathrm{OAc})_{2}(1.2 \mathrm{~g})$ was then added and the mixture was heated at $100{ }^{\circ} \mathrm{C}$ until reaction was complete as indicated by spectrophotometry (appearance of a Soret band, 30 min). The mixture was cooled and partitioned between $\mathrm{CH}_{2} \mathrm{Cl}_{2}$ and $\mathrm{H}_{2} \mathrm{O}$. The organic layer was extracted once with base and then dried over $\mathrm{Na}_{2} \mathrm{SO}_{4}$ and used directly in the next step. The crude copper(II) porphyrin was demetalated in the presence of ice cold $\mathrm{H}_{2} \mathrm{SO}_{4}$ /TFA (20/80, 20 $\mathrm{mL})$ during $6 \mathrm{~h}$. This acidic solution was washed successively with water $(100 \mathrm{~mL})$, aqueous $\mathrm{NaHCO}_{3}(3 \times 50 \mathrm{~mL})$ and then water again $(100 \mathrm{~mL})$ before being separated and evaporated to dryness. The crude porphyrin was placed on a silica gel column and eluted using $1 \%$ $\mathrm{MeOH} / \mathrm{CH}_{2} \mathrm{Cl}_{2}$. The red band was collected and crystallized from a minimum of $\mathrm{CH}_{2} \mathrm{Cl}_{2} / \mathrm{MeOH}$ to give red crystals of the title compound 20a (0.20 g, 42\% yield), mp 195-200 ${ }^{\circ} \mathrm{C}$. ${ }^{1} \mathrm{H}-\mathrm{NMR}$ : $\left(\mathrm{CDCl}_{3}\right) \delta 10.13$ (s, $1 \mathrm{H}$, meso-H), 10.05 (s, 1H, meso-H), 10.04 (s, 1H, meso-H), 10.03 (s, 1H, meso-H), 4.55 (t, 4H, - $\mathrm{CH}_{2}-\mathrm{CH}_{2}-\mathrm{Cl}$ ), 4.33 (t, 4H, $-\mathrm{CH}_{2}-\mathrm{CH}_{2}-\mathrm{Cl}$ ), 4.10 (t, 4H, - $\mathrm{CH}_{2}-\mathrm{CH}_{2}-\mathrm{CH}_{2}-$ $\mathrm{CH}_{2}-\mathrm{CO}_{2} \mathrm{CH}_{3}$ ), 3.68 (s, $6 \mathrm{H},-\mathrm{CO}_{2} \mathrm{CH}_{3}$ ), 3.63 (s, $\left.12 \mathrm{H},-\mathrm{CH}_{3}\right), 2.49$ (t, 4H, $-\mathrm{CH}_{2}-\mathrm{CH}_{2}-\mathrm{CH}_{2}-\mathrm{CH}_{2}-$ $\left.\mathrm{CO}_{2} \mathrm{CH}_{3}\right), 2.31$ (m, 4H, $\left.-\mathrm{CH}_{2}-\mathrm{CH}_{2}-\mathrm{CH}_{2}-\mathrm{CH}_{2}-\mathrm{CO}_{2} \mathrm{CH}_{3}\right), 2.08$ (m, 4H, $-\mathrm{CH}_{2}-\mathrm{CH}_{2}-\mathrm{CH}_{2}-\mathrm{CH}_{2}-$ 
$\mathrm{CO}_{2} \mathrm{CH}_{2}$ ). Anal. Calcd for $\mathrm{C}_{40} \mathrm{H}_{48} \mathrm{Cl}_{2} \mathrm{~N}_{4} \mathrm{O}_{4}$ : C, 66.82; H, 6.73; N, 7.80\% Found: C, 66.94; $\mathrm{H}$, 6.75; N, 7.55\% HRMS: $\mathrm{C}_{40} \mathrm{H}_{48} \mathrm{Cl}_{2} \mathrm{~N}_{4} \mathrm{O}_{4}$ requires $\mathrm{m} / \mathrm{z}$ 718.30524. Found 718.3048.

2,4-Bis(2-chloroethyl)-6,7-bis(6-ethoxycarbonylhexyl)-1,3,5,8-tetramethylporphyrin (20b). Using the same procedure as reported above, the title compound $20 \mathrm{~b}$ was obtained (0.30 g scale, 30\% yield), mp 151-153 ${ }^{\circ} \mathrm{C} .{ }^{1} \mathrm{H}-\mathrm{NMR}:\left(\mathrm{CDCl}_{3}\right) \delta 10.12$ (s, $1 \mathrm{H}$, meso-H), 10.05 (s, $1 \mathrm{H}$, meso-H), 10.04 (s, 1H, meso-H), 10.02 (s, 1H, meso-H), 4.54 (t, 4H, - $\mathrm{CH}_{2}-\mathrm{CH}_{2}-\mathrm{Cl}$ ), 4.33 (t, 4H, -CH $\mathrm{CH}_{2}-\mathrm{Cl}$ ), 4.06 (mq, 8H, $-\mathrm{CH}_{2}-\mathrm{CH}_{2}-\mathrm{CH}_{2}-\mathrm{CH}_{2}-\mathrm{CH}_{2}-\mathrm{CH}_{2}-\mathrm{CO}_{2} \mathrm{CH}_{2} \mathrm{CH}_{3}$ ), 3.69 (s, 3H, - $\mathrm{CH}_{3}$ ), 3.68 (s, 3H, - $\mathrm{CH}_{3}$ ), 3.67 (s, 3H, - $\mathrm{CH}_{3}$ ), 3.66 (s, 3H, - $\mathrm{CH}_{3}$ ), 2.29 (t, 4H, $-\mathrm{CH}_{2}-\mathrm{CH}_{2}-\mathrm{CH}_{2}-\mathrm{CH}_{2}-\mathrm{CH}_{2}-$ $\mathrm{CH}_{2}-\mathrm{CO}_{2} \mathrm{CH}_{2} \mathrm{CH}_{3}$ ), 1.70-1.65 (m, 8H, - $\mathrm{CH}_{2}-\mathrm{CH}_{2}-\mathrm{CH}_{2}-\mathrm{CH}_{2}-\mathrm{CH}_{2}-\mathrm{CH}_{2}-\mathrm{CO}_{2} \mathrm{CH}_{2} \mathrm{CH}_{3}$ ), 1.19 (t, 3H, $-\mathrm{CO}_{2}-\mathrm{CH}_{2}-\mathrm{CH}_{3}$ ). Anal. Calcd for $\mathrm{C}_{46} \mathrm{H}_{60} \mathrm{Cl}_{2} \mathrm{~N}_{4} \mathrm{O}_{4}$ : C, 68.79; H, 7.54; N, 6.98\% Found: C, 68.66; $\mathrm{H}, 7.02$; N, 6.53\% HRMS: $\mathrm{C}_{46} \mathrm{H}_{60} \mathrm{Cl}_{2} \mathrm{~N}_{4} \mathrm{O}_{4}$ requires $\mathrm{m} / \mathrm{z}$ 802.39913. Found 802.3992.

6,7-Bis(4-methoxycarbonylbutyl)-1,3,5,8-tetramethyl-2,4-divinylporphyrin (21a). To bischloroethylporphyrin 20a $(0.30 \mathrm{~g})$ in a $100 \mathrm{~mL}$ round-bottomed flask was added $40 \mathrm{~mL}$ pyridine and aqueous $3 \% \mathrm{KOH}$ solution $(20 \mathrm{~mL})$. This mixture was refluxed for $2.5 \mathrm{~h}$ in the dark and then cooled. Spectrophotometric analysis and TLC indicated that the vinyl groups had formed and that the esters were hydrolyzed to carboxylic acids. The crude mixture was then partitioned between $\mathrm{CH}_{2} \mathrm{Cl}_{2}(100 \mathrm{~mL})$ and an aqueous phosphate buffer solution $(100 \mathrm{~mL}, \mathrm{pH}=$ 4). The organic layer was washed once with water $(100 \mathrm{~mL})$. Crystallization attempts were unsuccessful, so the crude mixture was re-esterified by stirring the material overnight in 5\% $\mathrm{H}_{2} \mathrm{SO}_{4} / \mathrm{MeOH}(50 \mathrm{~mL})$. The mixture was worked up by dilution with $\mathrm{CH}_{2} \mathrm{Cl}_{2}(100 \mathrm{~mL})$ and washing with water and then saturated $\mathrm{NaHCO}_{3}$ solution. After washing again with water (100 $\mathrm{mL}$ ) the organic phase was evaporated. Purification using a silica gel column prepared with $1 \%$ $\mathrm{MeOH} / \mathrm{CH}_{2} \mathrm{Cl}_{2}$ yielded compound 21a (0.081 g, 30\%), mp 210-212 ${ }^{\circ} \mathrm{C} .{ }^{1} \mathrm{H}-\mathrm{NMR}:\left(\mathrm{CDCl}_{3}\right)$ $\delta 10.25$ (s, 1H, meso-H), 10.18 (s, 1H, meso-H), 10.10 (s, 1H, meso-H), 9.97 (s, 1H, meso-H), 8.32 (dd, $2 \mathrm{H},-\mathbf{H C}=\mathrm{CH}_{2}$ ), 6.40 (dd, $4 \mathrm{H},-\mathrm{HC}=\mathrm{CH}_{2}$ ), 4.08 (t, $4 \mathrm{H},-\mathrm{CH}_{2}-\mathrm{CH}_{2}-\mathrm{CH}_{2}-\mathrm{CH}_{2}-\mathrm{CO}_{2} \mathrm{CH}_{3}$ ), 3.72 (s, 6H, - $\mathrm{CO}_{2} \mathrm{CH}_{3}$ ), 3.62 (s, 12H, $-\mathrm{CH}_{3}$ ), 2.48 (t, 4H, $\left.-\mathrm{CH}_{2}-\mathrm{CH}_{2}-\mathrm{CH}_{2}-\mathrm{CH}_{2}-\mathrm{CO}_{2} \mathrm{CH}_{3}\right), 2.32$ (m, 4H, $-\mathrm{CH}_{2}-\mathrm{CH}_{2}-\mathrm{CH}_{2}-\mathrm{CH}_{2}-\mathrm{CO}_{2} \mathrm{CH}_{3}$ ), 2.07 (m, 4H, - $\mathrm{CH}_{2}-\mathrm{CH}_{2}-\mathrm{CH}_{2}-\mathrm{CH}_{2}-\mathrm{CO}_{2} \mathrm{CH}_{3}$ ). Anal. Calcd for $\mathrm{C}_{40} \mathrm{H}_{46} \mathrm{~N}_{4} \mathrm{O}_{4}$ : C, 74.26; H, 7.17; N, 8.67. Found: C, 74.29; H, 7.34; N, 8.83. LRMS: $\mathrm{C}_{40} \mathrm{H}_{46} \mathrm{~N}_{4} \mathrm{O}_{4}$ requires $\mathrm{m} / \mathrm{z}$ 646.4. Found 646.4. To obtain the dicarboxylic acid 4 the pure porphyrin was dissolved in $\mathrm{MeOH} / \mathrm{H}_{2} \mathrm{O} / \mathrm{KOH}(90 \mathrm{~mL} / 10 \mathrm{~mL} / 1 \mathrm{~g})$ and stirred under argon in the dark at room temperature overnight. Acidic work-up, followed by extraction into $\mathrm{CH}_{2} \mathrm{Cl}_{2}$ using a $\mathrm{pH} 4$ phosphate buffer as the aqueous phase led to the isolation of compound 4 (95\% yield) by crystallization from minimum $\mathrm{CH}_{2} \mathrm{Cl}_{2}$ and petroleum ether; $\mathrm{mp}>250{ }^{\circ} \mathrm{C}$. As is usually the case, a satisfactory elemental analysis of this porphyrin dicarboxylic acid could not be obtained (as follows); Anal. Calcd for $\mathrm{C}_{38} \mathrm{H}_{42} \mathrm{~N}_{4} \mathrm{O}_{4}$ : C, 69.69; H, 6.62; N, 8.56\% Found: C, 66.06; H, 6.42; N, 8.11\% LRMS: $\mathrm{C}_{38} \mathrm{H}_{42} \mathrm{~N}_{4} \mathrm{O}_{4}$ requires $\mathrm{m} / \mathrm{z}$ 618.3. Found 619.3.

6,7-Bis(6-methoxycarbonylhexyl)-1,3,5,8-tetramethyl-2,4-divinylporphyrin (21b). Using the same procedure as reported above, the title compound 21b was obtained (0.30 g scale, 30\% yield), mp 190-192 ${ }^{\circ} \mathrm{C}$. ${ }^{1} \mathrm{H}-\mathrm{NMR}:\left(\mathrm{CDCl}_{3}\right) \delta 10.26$ (s, 1H, meso-H), 10.19 (s, 1H, meso-H), 10.11 (s, 1H, meso-H), 9.99 (s, 1H, meso-H), 8.32 (dd, 2H, $-\mathbf{H C}=\mathrm{CH}_{2}$ ), 6.20 (dd, 4H, - 
$\left.\mathrm{HC}=\mathrm{CH}_{2}\right), 4.09\left(\mathrm{t}, 4 \mathrm{H},-\mathrm{CH}_{2}-\mathrm{CH}_{2}-\mathrm{CH}_{2}-\mathrm{CH}_{2}-\mathrm{CH}_{2}-\mathrm{CH}_{2}-\mathrm{CO}_{2} \mathrm{CH}_{3}\right), 3.74$ (s, 6H, $\left.-\mathrm{CO}_{2} \mathrm{CH}_{3}\right), 3.61$ (s, $12 \mathrm{H},-\mathrm{CH}_{3}$ ), 2.30 (t, 4H, $\left.-\mathrm{CH}_{2}-\mathrm{CH}_{2}-\mathrm{CH}_{2}-\mathrm{CH}_{2}-\mathrm{CH}_{2}-\mathrm{CH}_{2}-\mathrm{CO}_{2} \mathrm{CH}_{3}\right), 1.67$ (m, 8H, - $\mathrm{CH}_{2}-\mathrm{CH}_{2}-\mathrm{CH}_{2}-$ $\mathrm{CH}_{2}-\mathrm{CH}_{2}-\mathrm{CH}_{2}-\mathrm{CO}_{2} \mathrm{CH}_{3}$ ). Anal. Calcd for $\mathrm{C}_{44} \mathrm{H}_{54} \mathrm{~N}_{4} \mathrm{O}_{4}$ : C, 75.17; H, 7.28; N, 7.10. Found: C, 75.17; H, 7.75; N, 6.97. HRMS: $\mathrm{C}_{44} \mathrm{H}_{54} \mathrm{~N}_{4} \mathrm{O}_{4}$ requires $\mathrm{m} / \mathrm{z}$ 702.41448. Found 702.4153. To obtain the dicarboxylic acid 5, the pure porphyrin was dissolved in $\mathrm{MeOH} / \mathrm{H}_{2} \mathrm{O} / \mathrm{KOH}(90 \mathrm{~mL} / 10 \mathrm{~mL} / 1$ g) and stirred under argon in the dark at room temperature overnight. Acidic work-up, followed by extraction into $\mathrm{CH}_{2} \mathrm{Cl}_{2}$ using a $\mathrm{pH} 4$ phosphate buffer as the aqueous phase led to the isolation of compound 5 (95\% yield), $\mathrm{mp}>250{ }^{\circ} \mathrm{C}$, after crystallization from a minimum amount $\mathrm{CH}_{2} \mathrm{Cl}_{2}$

and petroleum ether. A satisfactory elemental analysis of this porphyrin dicarboxylic acid could not be obtained. LRMS: $\mathrm{C}_{42} \mathrm{H}_{50} \mathrm{~N}_{4} \mathrm{O}_{4}$ requires $\mathrm{m} / \mathrm{z}$ 674.4. Found 675.4.

\section{Acknowledgements}

This research was supported by the US National Institutes of Health, grant CA132861.

\section{References}

1. Fischer, H.; Orth, H. Die Chemie des Pyrrols; Akademische Verlag : Leipzig, 1937; Vol. II, part i, pp 390.

2. Kadish, K. M. In The Porphyrin Handbook; Smith, K. M.; Guliard, R. Eds.; Academic Press: Boston, 2003; Vol. 13, pp 49-108.

3. Perutz, M. F. Br. Med. Bull. 1975, 32, 195.

4. Smith, K. M.; Eivazi, F.; Martynenko, Z. J. Org. Chem. 1981, 46, 2189.

5. Tomaro, M. L.; Frydman, R. B.; Frydman, B.; Pandey, R. K.; Smith, K. M. Biochim. Biophys. Acta 1984, 791, 342.

6. (a) Pandey, R. K; Zheng, G. In The Porphyrin Handbook; Kadish, K. M.; Smith, K. M.; Guilard, R. Eds.; Academic Press: Boston, 2000; Vol. 6, pp 157. (b) Bonnett, R. Chemical Aspects of Photodynamic Therapy; CRC Press: Boca Raton, 2000, p 1.

7. Moan, J.; Berg, K.; Kvam, E.; Western, A.; Malik, Z.; Ruck, A.; Schneckenburger, H. In Photosensitizing Compounds: Their Chemistry, Biology and Clinical Use; Bock, G.; Mernett, S. Eds.; John Wiley: New York, 1989; pp 95.

8. Berg, K.; Moan, J. Photochem. Photobiol. 1997, 65, 403.

9. Specht, K. G.; Rodgers, M. A. J. Biochim. Biophys. Acta 1991, 1070, 60.

10. Ehrenberg, B.; Anderson, J. L.; Foote, C. S. Photochem. Photobiol. 1998, 68, 135.

11. Lavi, A.; Weitman, H.; Holmes, R. T.; Smith, K. M.; Ehrenberg, B. Biophys. J. 2002, 82, 2101.

12. Kepczynski, M.; Pandian, R. P.; Smith. K. M.; Ehrenberg, B. Photochem. Photobiol. 2002, 76, 127.

13. Bronshtein, I.; Afri, M.; Weitman,H.; Frimer, A. A.; Smith, K. M.; Ehrenberg, B. Biophys. J. 2004, 87, 1155. 
14. Bronshtein, I.; Smith, K. M.; Ehrenberg, B. Photochem. Photobiol. 2005, 81, 446.

15. Bronshtein, I.; Aulova, S.; Juzeniene, A.; Iani, V.; Ma, L.-W.; Smith, K. M.; Malik, Z.; Moan, J.; Ehrenberg, B. Photochem. Photobiol. 2006, 82, 1319.

16. Cavaleiro, J. A. S.; Rocha Gonsalves, A. M. d’A.; Kenner, G. W.; Smith, K. M. J. Chem. Soc., Perkin Trans. 1. 1974, 1771.

17. Cavaleiro, J. A. S.; Rocha Gonsalves, A. M. d’A.; Kenner, G. W.; Smith, K. M. J. Chem. Soc., Perkin Trans. 1. 1973, 2471.

18. Carr, R. P.; Jackson, A. H.; Kenner, G. W.; Sach, G. S. J. Chem. Soc. (C) 1971, 487.

19. Smith, K. M.; Craig, G. W.; Eivazi, F.; Martynenko, Z. Synthesis 1980, 493.

20. Johnson, A. W.; Markham, E.; Price, R.; Shaw, K. B. J. Chem. Soc. 1958, 4254.

21. Griffith, W. P.; Ley, S. V.; Whitcombe, G. P.; White, A. D. J. Chem. Soc., Chem. Commun. 1988, 1625.

22. Smith, K. M. In The Porphyrin Handbook; Kadish, K. M.; Smith, K. M.; Guilard, R. Eds.; Academic Press: Boston, 2000; Vol. 1, pp 119. 